\title{
PERILAKU IMPOR SUSU DI INDONESIA
}

\author{
Hastuty Pratiwi \\ Fakultas Ekonomi, Universitas Islam Indonesia \\ hastutypratiwi@yahoo.com \\ Abdul Hakim \\ Fakultas Ekonomi, Universitas Islam Indonesia \\ abdul.hakim.uii@gmail.com
}

\begin{abstract}
This paper analyzes the behaviour of milk import in Indonesia during 19852010. Using an Error Correction Model (ECM), it finds that in the long run, factors influencing the milk import are percapita income, domestic milk real price, and imported milk price. In the short run, the import is influenced by population size of more than 5-year old residents, real domestic price milk, real price of imported milk, and exchange rates. Variables that do not influence milk imports, both in the short run and in the long run, are national milk production, milk exports, population size of less than 5-year old residents, and the gonvernment policy on the deletion of milk imports.
\end{abstract}

Keywords: milk import, ECM, percapita income, milk price, exchange rates, government policy JEL classification numbers: F13, F14

\section{PENDAHULUAN}

Indonesia memiliki ketergantungan impor yang sangat tinggi, yakni mencapai $74 \%$ dari total kebutuhan susu nasional. Perkembangan agribinis belum mampu membangun daya saing yang tinggi dan belum optimal dalam memanfaatkan keunggulan komparatif yang dimiliki. Pada sisi lain, konsumsi pangan sebagian masyarakat yang berpendapatan menengah dan tinggi terus mengalami pertumbuhan. Indonesia terpaksa mengimpor komoditas pangan dalam jumlah relatif besar seperti beras, jagung, kedelai, daging, dan susu untuk memenuhi kebutuhan masyarakat.

Ketika pemerintah terlampau berfokus pada usaha peningkatan produksi beras, sektor peternakan menjadi terabaikan. Populasi ternak seperti sapi, kerbau, dan kambing terus mengalami penurunan sehingga berpengaruh 
terhadap produksi hasil olahannya seperti daging dan susu, padahal pertumbuhan konsumsi pangan masyarakat Indonesia terus terjadi.

Salah satu produk pangan Indonesia yang terus mengalami peningkatan permintaan adalah susu. Peningkatan tersebut ditandai dengan meningkatnya konsumsi susu per kapita dari tahun ke tahun. Tabel 1 menunjukkan tingkat konsumsi susu di Indonesia.

Tabel 1. Jumlah Produksi dan Konsumsi Susu di Indonesia (2001-2009)

\begin{tabular}{ccc}
\hline Tahun & Produksi ( Ton) & Konsumsi Susu (Ton) \\
\hline 2001 & 479.947 & 883.758 \\
2002 & 493.375 & 889.934 \\
2003 & 553.442 & 1.133 .091 \\
2004 & 549.945 & 957.624 \\
2005 & 535.962 & 845.744 \\
2006 & 616.549 & 1.621 .524 \\
2007 & 567.638 & 1.758 .243 \\
2008 & 574.406 & 2.054 .249 \\
$2009^{*}$ & 590.894 & 2.400 .090 \\
\hline
\end{tabular}

Keterangan: * Angka Sementara

Sumber: Direktorat Jenderal Peternakan (2010)

Menurut Tabel 1, konsumsi susu masyarakat Indonesia terus meningkat dari 883.758 ton pada tahun 2001 menjadi 2.400 .090 ton pada tahun 2009. Akan tetapi, kecepatan peningkatan konsumsi susu nasional tersebut tidak selaras dengan peningkatan produksi susu nasional. Untuk memenuhi permintaan masyarakat, pemerintah melakukan impor susu dari beberapa negara, terutama Australia, Perancis, dan Selandia Baru.

Meskipun Indonesia juga mengekspor susu olahan ke beberapa negara tetangga, akan tetapi volume impor susu Indonesia jauh lebih besar daripada volume ekspornya. Tabel 2 memperlihatkan perkembangan ekspor susu olahan dan impor susu di Indonesia. 
Tabel 2. Perkembangan Ekspor Susu dan Impor Susu Indonesia (2003-2009)

\begin{tabular}{ccc}
\hline Tahun & Volume Ekspor $(\mathrm{Kg})$ & Volume Impor $(\mathrm{Kg})$ \\
\hline 2003 & 49.593 .646 & 117.318 .145 \\
2004 & 40.935 .091 & 165.411 .493 \\
2005 & 45.018 .446 & 173.084 .444 \\
2006 & 35.384 .733 & 133.486 .409 \\
2007 & 27.281 .268 & 141.025 .464 \\
2008 & 23.749 .414 & 151.039 .188 \\
$2009^{*}$ & 20.674 .797 & 161.763 .950 \\
\hline
\end{tabular}

Keterangan: * Angka Sementara

Sumber: Direktorat Jenderal Peternakan (2010)

Tabel 2 memperlihatkan bahwa volume ekspor susu dan produk susu tertinggi dicapai pada tahun 2003 sebesar $49.593 .646 \mathrm{~kg}$. Volume impor tertinggi dicapai pada tahun 2005 sebesar $173.084 .444 \mathrm{~kg}$. Tingginya volume impor disebabkan oleh rendahnya produktivitas peternak dan produksi susu nasional yang belum mampu memenuhi permintaan Industri Pengolahan Susu (IPS) dan kebutuhan masyarakat.

Pengembangan sektor peternakan khususnya usaha ternak sapi perah perlu dilakukan karena kemampuan pasokan susu peternak lokal saat ini baru mencapai 25 persen sampai 30 persen dari kebutuhan susu nasional (Direktorat Jenderal Peternakan, 2010). Besamya jumlah impor susu nasional tersebut menunjukkan prospek pasar yang sangat besar dalam usaha peternakan sapi perah untuk menghasilkan susu segar sebagai produk substitusi impor.

Mengingat kondisi geografis, ekologi, dan kesuburan lahan di beberapa wilayah Indonesia memiliki karakteristik yang cocok untuk pengembangan agribisnis persusuan serta besarnya kekurangan pasokan susu dalam negeri, banyak sekali kerugian yang diperoleh Indonesia akibat dilakukannya impor susu. Di antara kerugian tersebut ialah terkurasnya devisa nasional, hilangnya kesempatan terbaik (opportunity loss) yang berasal dari menganggurnya potensi sumberdaya yang ada untuk pengembangan agribisnis persusuan, dan hilangnya potensi pendapatan yang seharusnya diperoleh pemerintah dari pajak apabila agribisnis persusuan dikembangkan secara baik.

Mengingat berbagai hal di atas, analisis faktor-faktor yang dapat mempengaruhi impor susu di Indonesia perlu dilakukan agar nantinya pemerintah dapat membuat kebijakan dan strategi peningkatan produksi dan kualitas susu. Pemerintah diharapkan dapat mengentaskan masalah ketergantungan akan 
impor susu, oleh karena itu penulis merasa tertarik untuk mengadakan penelitian dengan judul Perilaku Impor Susu di Indonesia.

\section{Kajian Pustaka}

Beberapa peneliti telah melakukan analisis terhadap impor susu Indonesia. Keanekaragaman penelitian berbeda dari variabel yang dianalisis serta model atau metode analisis yang digunakan. Amaliah dan Fahmi (2008) menganalisis faktor-faktor yang mempengaruhi daya saing dan impor susu Indonesia periode 1976-2005. Variabel yang digunakan adalah volume impor susu indonesia, volume produksi, harga riil susu domestik, harga riil susu impor, pendapatan perkapita, dan nilai tukar riil IDR/USD. Dengan menggunakan metode EngleGranger Cointegration dan Error Correction Model (ECM), dia menemukan bahwa impor susu Indonesia dalam jangka panjang dipengaruhi secara signifikan oleh harga riil susu domestik, harga riil susu impor, pendapatan perkapita, dan nilai tukar riil IDR/USD. Impor susu Indonesia pada jangka pendek dipengaruhi secara signifikan oleh volume produksi, harga riil susu impor, pendapatan perkapita, dan nilai tukar riil IDR/USD.

Sinaulan (1994) meneliti faktor-faktor yang mempengaruhi tingkat permintaan dan penawaran susu sapi perah di Jawa Barat. Variabel yang digunakan adalah harga susu sapi perah, pendapatan yang tercermin dari PDRB, jumlah penduduk, jumlah populasi sapi perah, dan tingkat penawaran dan permintaan susu sapi perah. Dengan menggunakan regresi linier berganda, dia menemukan bahwa harga susu sapi, pendapatan, dan jumlah penduduk secara serempak berpengaruh signifikan terhadap permintaan susu sapi perah.

Siregar (2003) menghitung dampak penghapusan tarif impor susu terhadap daya saing komoditi susu sapi lokal. Dia memasukkan harga susu sapi, pendapatan, jumlah penduduk, dan tingkat penawaran dan permintaan sebagai variabel independen, serta menggunakan policy analysis matrix (PAM) dan analisis sensitivitas untuk melihat perubahan daya saing jika terjadi perubahan tarif impor. Hasil analisis dengan menggunakan PAM menunjukkan bahwa pengusahaan sapi perah untuk menghasilkan susu sapi segar di TPK Cibedug, KPSBU Jabar memiliki daya saing baik secara finansial maupun ekonomi walaupun dalam kondisi tarif impor susu sebesar nol persen. Hasil analisis sensitivitas yang dilakukan menunjukkan bahwa adanya penghapusan tarif impor susu menyebabkan berkurangnya daya saing komoditi susu sapi lokal.

Kustiari dkk. (2008) meneliti kebijakan impor susu dalam kaitannya dengan upaya melindungi peternak dan konsumen. Variabel yang digunakan adalah harga susu sapi, pendapatan perkapita, jumlah penduduk, dan tingkat penawaran dan permintaan. Dengan menggunakan regresi linier berganda, 
mereka menunjukkan bahwa peningkatan tarif impor meningkatkan harga susu di pasar domestik.

Ahmad dan Hermiyetti (2008) menganalisis produksi dan konsumsi susu menggunakan variabel pengeluaran rumahtangga, dummy variabel pendidikan kepala rumah tangga, jumlah anggota rumah tangga, dan jumlah balita dalam rumah tangga. Dengan menggunakan analisis regresi, mereka menemukan bahwa pengeluaran rumah tangga mempunyai pengaruh positif dan signifikan terhadap konsumsi susu bubuk, susu bubuk bayi dan susu kental manis.

Dari pertimbangan di atas, maka penelitian ini menggunakan variabel produksi susu nasional, pendapatan perkapita, ekspor susu, jumlah balita, jumlah penduduk non balita, harga riil susu domestik, harga riil susu impor, nilai tukar, dan variabel dummy kebijakan pemerintah tahun 1998. Alat analisis yang digunakan adalah Error Correction Model atau model koreksi kesalahan karena dapat mengetahui pengaruh jangka pendek dan jangka panjang dari variabel independen terhadap variabel dependen (Isbandriyati, 2009). Diperkirakan juga beberapa variabel-variabel yang dianalisis tidak stasioner, dan terdapat gejala kointegrasi diantara mereka.

\section{Teori Permintaan Impor}

Perdagangan internasional memungkinkan sebuah negara berspesialisasi memproduksi barang-barang tertentu sehingga memungkinkan mereka mencapai tingkat efisiensi yang lebih tinggi dengan skala produksi yang lebih besar (Halwani, 2002). Faktor-faktor umum yang mendorong terjadinya perdagangan internasional adalah perbedaan sumber daya alam, sumber daya modal, tenaga kerja, dan teknologi.

Menurut konsep permintaan impor tradisional, faktor dominan penentu permintaan impor adalah pendapatan penduduk, yang diukur dengan Produk Domestik Bruto riil, dan harga relatif impor. Impor merupakan kelebihan permintaan domestik, sehingga perekonomian dalam negeri mengalokasikan pembelanjaannya meliputi pembelian barang dan jasa dari luar negeri. Secara konseptual, permintaan impor sama dengan model permintaan pada umumnya, yang merupakan permintaan suatu negara terhadap produk luar negeri.

Beberapa variabel yang penting akan dijelaskan definisi operasionalnya berikut ini. Pertama, pendapatan perkapita adalah pendapatan rata-rata penduduk, mengukur kemampuan penduduk untuk berbelanja, yang sebagian di antaranya akan berupa belanja impor.

Kedua, ekspor merupakan total barang dan jasa yang dijual oleh sebuah negara ke negara lain (Sjoholm dan Lindh, 1997). Ekspor merupakan faktor 
penting dalam merangsang pertumbuhan ekonomi suatu negara. Ekspor akan memperbesar kapasitas konsumsi suatu negara serta membantu menjalankan usaha-usaha pembangunan mereka melalui promosi serta penguatan sektorsektor ekonomi yang mengandung keunggulan komparatif. Namun, ekspor susu juga ditengarai akan mengurangi suplai susu nasional sehingga penduduk terpaksa mengimpor sebagian susu yang dibutuhkan.

Ketiga, balita adalah istilah umum bagi anak usia 1-3 tahun (batita) ditambah anak prasekolah (3-5 tahun) (Sutomo dan Anggraeni, 2010). Masa balita merupakan periode penting dalam proses tumbuh kembang manusia sehingga dihipotesiskan mempengaruhi permintaan susu, baik produk lokal maupun impor.

Keempat, pertumbuhan penduduk meningkatkan output melalui ekspansi pasar baik pasar dalam negeri maupun luar negeri. Jumlah penduduk dihipotesiskan juga mempengaruhi kebutuhan susu, baik domestik maupun impor. Pengaruh variabel ini terhadap impor susu dibedakan dari pengaruh jumlah balita karena diharapkan konsumsi susu dua kelompok usia penduduk tersebut berbeda secara signifikan.

Kelima, harga adalah perwujudan nilai tukar atas suatu barang/jasa yang dinyatakan dalam uang. Oleh karena itu, harga merupakan nilai tukar obyektif atas barang/jasa. Pada penelitian ini, harga yang digunakan adalah harga riil domestik dan harga riil impor. Harga riil domestik merupakan besaran harga yang ditetapkan oleh pihak produsen dipasar domestik yang diukur menggunakan rupiah dan harga riil impor merupakan harga transaksi antara pengimpor dan pengekspor dalam pasar Internasional.

Keenam, kurs adalah perbandingan nilai atau harga mata uang nasional tertentu dengan mata uang nasional lain. Disamping berperan dalam perdagangan internasional, kurs juga berperan dalam perdagangan valuta asing pada suatu negara ataupun antar negara, sebab valuta asing juga merupakan komoditas yang dapat diperdagangkan. Ketujuh, kebijakan pemerintah. Berbagai kebijakan pemerintah telah dibuat terkait dengan industri susu nasional. Salah satu kebijakan yang dianggap penting dan dimasukkan dalam analisis ini adalah penghapusan kebijakan rasio impor yang ditetapkan oleh pemerintah per tahun 1998 berupa peningkatan volume impor.

\section{METODE PENELITIAN}

\section{Jenis dan Sumber Data Penelitian}

Penelitian ini menggunakan data runtun waktu. Variabel terikat adalah impor susu, sedangkan sembilan variabel bebas adalah produksi nasional, pendapatan perkapita, ekspor, jumlah balita, jumlah penduduk non balita, 
harga riil susu domestik, harga riil susu impor, nilai tukar IDR/USD, dan dummy penghapusan kebijakan rasio impor 1998. Data tersebut diperoleh dari Badan Pusat Statistik Daerah Istimewa Yogyakarta, dan data lain yang bersumber dari referensi kepustakaan melalui makalah, artikel, jurnal, dan bahan-bahan lain. Data, satuan dan sumbernya ditayangkan dalam tabel berikut ini.

Tabel 3. Data, Satuan dan Sumbernya

\begin{tabular}{lcc}
\hline \multicolumn{1}{c}{ Nama Variabel } & Satuan & Sumber \\
\hline Nilai impor susu & USD juta & BPS \\
Produksi susu nasional & IDR juta & BPS \\
Pendapatan per kapita & Rp per orang & BPS \\
Nilai ekspor susu & USD juta & BPS \\
Jumlah balita & Orang & BPS \\
Jumlah penduduk non balita & Orang & BPS \\
Harga riil susu domestik & Rupiah per liter & BPS \\
Kurs & IDR/USD & OANDA \\
\hline Dummy kebijakan & Penghapusan kebijakan & \\
pemerintah & rasio impor \\
\hline
\end{tabular}

Catatan: BPS = Badan Pusat Statistik.

OANDA bisa diakses di http://www.oanda.com/currency/historical-rates/

\section{Metode Analisis Data}

Metode analisis yang digunakan untuk mengetahui hubungan antar variabel adalah model koreksi kesalahan atau Error Correction Models (ECM). Pengolahan data dalam penelitian ini menggunakan software Microsoft Excel dan Eviews 5.0. Model ECM digunakan untuk mengetahui pengaruh jangka pendek dan jangka panjang dari variabel independen terhadap variabel dependen (Isbandriyati, 2009).

Untuk penelitian menggunakan data time series, langkah standar pertama adalah menguji stasioneritas data. Variabel dikatakan tidak stasioner jika terdapat hubungan antara variabel tersebut dengan waktu atau trend. Model yang mengandung variabel yang tidak stasioner sering menimbulkan masalah regresi lancung atau spurious regression, yaitu hasil estimasi yang diperoleh dari model secara statistik signifikan tetapi pada kenyataannya secara ekonomi tidak memiliki arti apapun. Oleh karena itu, setelah data diketahui tidak stasioner, maka langkah selanjutnya adalah melakukan uji derajat integrasi. 
Uji derajat integrasi merupakan konsekuensi dari tidak terpenuhinya asumsi stasioneritas pada derajat nol. Pada uji ini variabel yang diamati di-difference pada derajat tertentu, sehingga semua variabel stasioner pada derajat yang sama. Suatu variabel dikatakan stasioner pada first difference jika nilai $A D F_{u j i}$ lebih kecil dari nilai kritis McKinnon setelah di-difference satu kali.

Jika dua buah atau lebih variabel stasioner pada derajat 1 , tetapi memiliki keseimbangan jang panjang, maka variabel-variable tersebut berokintegrasi. Dalam situasi ini, model yang tepat untuk digunakan adalah error correction model (ECM). ECM bisa mengatasi perbedaan kekonsistenan hasil estimasi antara jangka pendek dan jangka panjang, yaitu dengan cara proporsi disequilibrium pada satu periode dikoreksi pada periode selanjutnya sehingga tidak ada kesalahan dalam menggunakan model yang dianalisis (Isbandriyati, 2009).

Keuntungan dan keunggulan penggunaan ECM yang lain yaitu seluruh komponen dan informasi pada tingkat variabel telah dimasukkan dalam model, memasukkan semua bentuk kesalahan untuk dikoreksi, dapat terhindar dari masalah trend dan regresi lancung (spurious regression), sifat-sifat statistik yang diinginkan dari model dan pemberian makna dari persamaan dalam model tersebut lebih sederhana. Artinya, ECM mampu memberikan makna lebih luas dari estimasi model ekonomi sebagai pengaruh perubahan variabel independen terhadap variabel dependen dalam hubungan jangka pendek maupun jangka panjang (Siregar, 2004).

Ketidakseimbangan kesalahan (disequilibrium error) terjadi karena kesalahan spesifikasi, yaitu antara lain kesalahan pemilihan variabel, parameter dan keseimbangan itu sendiri serta kesalahan membuat definisi variabel dan cara mengukurnya. Selanjutnya, kesalahan yang disebabkan oleh faktor manusia dalam menginput data. Adapun persamaan yang akan digunakan dalam penelitian ECM adalah sebagai berikut:

$$
\begin{aligned}
\Delta Y_{t}= & \beta_{0}+\beta_{1} \Delta X_{1 t}+\beta_{2} \Delta X_{2 t}+\beta_{3} \Delta X_{3 t}+\beta_{4} \Delta X_{4 t}+\beta_{5} \Delta X_{5 t}+\beta_{6} \Delta X_{6 t}+\beta_{7} \Delta X_{7 t} \\
& +\beta_{8} \Delta X_{8 t}+\beta_{9} X_{9 t}+\beta_{0} X_{1 t-1}+\beta_{1} X_{2 t-1}+\beta_{\mathrm{q}} X_{3 t-1}+\beta_{\mathrm{b}} X_{4 t-1} \\
& +\beta_{4 t} X_{5 t-1}+\beta_{5} X_{6 t-1}+\beta_{6} X_{7 t-1}+\beta_{7} X_{8 t-1}+\beta_{8} E C T_{t}+U_{t}
\end{aligned}
$$

dimana

$$
\begin{array}{ll}
Y & =\text { Impor } \\
X_{1} & =\text { Produksi nasional } \\
X_{2} & =\text { Pendapatan perkapita } \\
X_{3} & =\text { Ekspor susu }
\end{array}
$$




$$
\begin{array}{ll}
X_{4} & =\text { Jumlah balita } \\
X_{5} & =\text { Jumlah penduduk non balita } \\
X_{6} & =\text { Harga riil susu domestik } \\
X_{7} & =\text { Harga riil susu impor } \\
X_{8} & =\text { Nilai tukar IDR/USD } \\
X_{9} & =\text { Dummy penghapusan kebijakan rasio impor } \\
\beta_{0} & =\text { Konstanta regresi } \\
\beta_{1, \cdots,} \beta_{8} & =\text { Koefisien regresi }
\end{array}
$$

\section{ANALISIS DATA}

\section{Uji Akar-akar Unit}

Uji akar unit yang digunakan dalam penelitian ini adalah uji Augmented Dickey Fuller (ADF). Apabila nilai t-statistik ADF lebih kecil daripada nilai kritis MacKinnon, maka variabel tersebut memiliki akar unit sehingga dikatakan tidak stasioner pada taraf nyata tertentu. Hasil uji ADF untuk data time series setiap variabel pada tingkat level dapat dilihat pada Tabel 4.

Tabel 4. Hasil Estimasi Akar-akar Unit pada Ordo Nol (Level)

\begin{tabular}{cccccc}
\hline & Nilai ADF $\mathrm{t}$ & \multicolumn{4}{c}{ Nilai kritis MacKinnon } \\
\cline { 3 - 6 } Variabel & statistic & 1 persen & 5 persen & 10 persen & Keterangan \\
\hline $\log Y$ & 0.046369 & -3.75295 & -2.99806 & -2.63875 & Tidak stasioner \\
$\log X_{1}$ & 0.060526 & -3.72407 & -2.98623 & -2.6326 & Tidak stasioner \\
$\operatorname{LogX}_{2}$ & 0.236821 & -3.72407 & -2.98623 & -2.6326 & Tidak stasioner \\
$\operatorname{LogX}_{3}$ & -0.82536 & -3.73785 & -2.99188 & -2.63554 & Tidak stasioner \\
$\log X_{4}$ & -0.5372 & -3.72407 & -2.98623 & -2.6326 & Tidak stasioner \\
$\log X_{5}$ & -3.84546 & -3.72407 & -2.98623 & -2.6326 & Stasioner \\
$\log X_{6}$ & -0.94599 & -3.73785 & -2.99188 & -2.63554 & Tidak stasioner \\
$\operatorname{LogX}_{7}$ & -0.21991 & -3.72407 & -2.98623 & -2.6326 & Tidak stasioner \\
$\log X_{8}$ & -1.38393 & -3.72407 & -2.98623 & -2.6326 & Tidak stasioner \\
Dummy & -0.88231 & -3.72407 & -2.98623 & -2.6326 & Tidak stasioner \\
\hline
\end{tabular}


Tabel 4 memperlihatkan bahwa terdapat sembilan variabel yang tidak stasioner pada level, yakni impor susu ( $\log Y)$, produksi nasional $\left(\log X_{1}\right)$, pendapatan perkapita $\left(\log X_{2}\right)$, ekspor susu $\left(\log X_{3}\right)$, jumlah balita $\left(\log X_{4}\right)$, harga riil susu domestik $\left(\log X_{5}\right)$, harga riil susu impor $\left(\log X_{6}\right)$, kurs dalam bentuk IDR/USD $\left(\log X_{7}\right)$ dan dummy penghapusan kebijakan rasio impor. Hal ini dapat ditunjukkan dengan nilai ADF t statistik lebih kecil daripada nilai kritis MacKinnon baik pada tingkat signifikansi $1 \%, 5 \%$ maupun $10 \%$. Sedangkan variabel yang dinyatakan stasioner hanya terjadi pada variabel jumlah penduduk non balita $\left(\log X_{5}\right)$.

Berdasarkan hal tersebut, maka kembali dilakukan pengujian Augmented Dickey Fuller Test lanjutan pada tingkat first difference, dan hasilnya dapat ditunjukkan pada tabel berikut:

Tabel 5. Hasil Uji Augmented Dickey Fuller pada First Difference

\begin{tabular}{cccccc}
\hline & Nilai ADF t & \multicolumn{4}{c}{ Nilai kritis MacKinnon } \\
\cline { 3 - 6 } Variabel & statistic & 1 persen & 5 persen & 10 persen & Keterangan \\
\hline $\log \mathrm{Y}$ & -5.48318 & -3.75295 & -2.99806 & -2.63875 & Stasioner \\
$\log \mathrm{X}_{1}$ & -5.2652 & -3.73785 & -2.99188 & -2.63554 & Stasioner \\
$\log \mathrm{X}_{2}$ & -6.00764 & -3.73785 & -2.99188 & -2.63554 & Stasioner \\
$\log \mathrm{X}_{3}$ & -8.42824 & -3.73785 & -2.99188 & -2.63554 & Stasioner \\
$\log \mathrm{X}_{4}$ & -4.52699 & -3.73785 & -2.99188 & -2.63554 & Stasioner \\
$\log \mathrm{X}_{5}$ & -3.47612 & -3.73785 & -2.99188 & -2.63554 & Stasioner \\
$\log \mathrm{X}_{6}$ & -3.40566 & -3.73785 & -2.99188 & -2.63554 & Stasioner \\
$\log \mathrm{X}_{7}$ & -3.73225 & -3.73785 & -2.99188 & -2.63554 & Stasioner \\
$\log \mathrm{X}_{8}$ & -4.50084 & -3.73785 & -2.99188 & -2.63554 & Stasioner \\
Dummy & -4.89898 & -3.73785 & -2.99188 & -2.63554 & Stasioner \\
\hline
\end{tabular}

Tabel 5 menunjukkan bahwa semua data yang digunakan dalam penelitian ini stasioner pada first difference, pada tingkat signifikansi $1 \%, 5 \%$ maupun $10 \%$, artinya data stasioner pada pembedaan pertama. Karena data stasioner pada derajat yang sama (derajat pertama).

\section{Uji Kointegrasi}

Uji kointegrasi merupakan kelanjutan dari uji akar unit dan uji derajat integrasi. Uji kointegrasi dimaksudkan untuk menguji apakah residual regresi yang dihasilkan stasioner atau tidak (Engle dan Granger, 1987). Apabila terjadi satu atau lebih peubah mempunyai derajat integrasi yang berbeda, maka peubah 
tersebut tidak dapat berkointegrasi (Engle dan Granger, 1987). Pada umumnya, sebagian besar pembahasan memusatkan perhatiannya pada peubah yang berintegrasi nol atau satu. Apabila langsung stasioner ketika membuat regresi antara peubah bebas dan peubah terikat, maka dapat dinyatakan bahwa antara peubah bebas dan peubah terikat terkointegrasi pada derajat nol atau dinotasikan dengan $I(0)$. Tetapi apabila stasioner pada pembedaan pertama, maka kedua peubah tersebut terkointegrasi pada derajat pertama atau dinotasikan dengan I(1).

Uji kointegrasi Engle-Granger digunakan untuk mengestimasi hubungan jangka panjang antara volume impor $(\log Y)$ dengan produksi nasional $\left(\log X_{1}\right)$ pendapatan perkapita $\left(\log X_{2}\right)$, ekspor susu $\left(\log X_{3}\right)$, jumlah balita $\left(\log X_{4}\right)$, jumlah penduduk non balita $\left(\log X_{5}\right)$, harga riil susu domestik $\left(\log X_{6}\right)$, harga riil susu impor $\left(\log X_{7}\right)$, kurs dalam bentuk IDR/USD $\left(\log X_{8}\right)$, dan dummy penghapusan kebijakan rasio impor. Tahap awal dari uji kointegrasi Engle-Granger adalah dengan meregresi persamaan OLS antara variabel dependen dan variabel independen. Kemudian setelah meregresi persamaan didapatkan residual dari persamaan tersebut. Uji ADF pada residual bersifat stasioner pada level atau I(0) sehingga dapat dikatakan bahwa variabel yang digunakan cenderung menuju keseimbangan pada jangka panjang walaupun pada tingkat level terdapat variabel yang tidak stasioner.

Tabel 6. Nilai Regresi Uji Kointegrasi

\begin{tabular}{cccccc}
\hline & Nilai ADF $\mathrm{t}$ & \multicolumn{4}{c}{ Nilai kritis MacKinnon } \\
\cline { 3 - 6 } Variabel & statistic & 1 persen & 5 persen & 10 persen & Keterangan \\
\hline Ue & -5.80403 & -3.73785 & -2.99188 & -2.63554 & Stasioner \\
\hline
\end{tabular}

Sumber: Data diolah, 2008

Berdasarkan informasi yang tertuang dalam Tabel 6, diketahui bahwa nilai ADF t-statistic lebih besar daripada nilai kritis MacKinnon pada taraf nyata 1 persen, 5 persen, maupun 10 persen, sehingga residual persamaan regresi stasioner pada tingkat level.

\section{Error Correction Model (ECM)}

Model Koreksi Kesalahan (Error Correction Model) merupakan metode pengujian yang dapat digunakan untuk mencari model keseimbangan dalam jangka panjang. Untuk menyatakan apakah model ECM yang digunakan sahih atau tidak maka koefisien Error Corection Term (ECT) harus signifikan. Jika koefisien ini tidak signifikan maka model tersebut tidak cocok dan perlu dilakukan perubahan spesifikasi lebih lanjut. Hasil pengolahan data yang dilakukan dengan 
menggunakan bantuan program komputer EViews, dengan model regresi linear ECM ditampilkan sebagai berikut;

\begin{tabular}{|c|c|c|c|}
\hline Variabel & Coefficient & t-Statistic & Prob. \\
\hline C & -343.410 & -2.863 & 0.046 \\
\hline DLOGX $_{1}$ & 0.821 & 1.602 & 0.184 \\
\hline DLOGX $_{2}$ & -1.516 & -3.778 & 0.020 \\
\hline $\operatorname{DLOGX}_{3}$ & 0.429 & 1.257 & 0.277 \\
\hline DLOGX $_{4}$ & 0.708 & 0.064 & 0.952 \\
\hline DLOGX $_{5}$ & -15.408 & -0.667 & 0.541 \\
\hline DLOGX $_{6}$ & -3.770 & -2.192 & 0.093 \\
\hline DLOGX $_{7}$ & 1.709 & 2.615 & 0.059 \\
\hline DLOGX $_{8}$ & 0.864 & 1.896 & 0.131 \\
\hline DUMMY & -0.072 & -0.115 & 0.914 \\
\hline $\operatorname{LOGX}_{1}(-1)$ & 0.544 & 0.923 & 0.408 \\
\hline $\operatorname{LOGX}_{2}(-1)$ & -0.619 & -0.403 & 0.707 \\
\hline $\operatorname{LOGX}_{3}(-1)$ & 0.771 & 1.515 & 0.204 \\
\hline $\operatorname{LOGX}_{4}(-1)$ & 0.281 & 0.064 & 0.952 \\
\hline $\operatorname{LOGX}_{5}(-1)$ & 17.842 & 2.721 & 0.053 \\
\hline $\operatorname{LOGX6(-1)}$ & -5.967 & -2.096 & 0.104 \\
\hline $\operatorname{LOGX}_{7}(-1)$ & 1.540 & 2.623 & 0.059 \\
\hline $\operatorname{LOGX}_{8}(-1)$ & 1.862 & 2.339 & 0.080 \\
\hline DUMMY(-1) & -0.156 & -0.456 & 0.672 \\
\hline ECT & 1.528 & 3.394 & 0.027 \\
\hline
\end{tabular}

Berdasarkan hasil estimasi model dinamis ECM di atas, maka dapat dilihat pada variabel Error Correction Term (ECT) nya signifikan pada tingkat signifikansi $5 \%$ dengan probabilitas sebesar $0,027<0,05$, maka spesifikasi model sudah sahih dan dapat menjelaskan variasi pada variabel tak bebas.

Untuk mengetahui apakah hasil estimasi dapat dipercaya maka dilakukan pengujian lebih lanjut yaitu berupa uji ekonometri. Uji tersebut dimaksudkan untuk mengetahui apakah penafsiran-penafsiran terhadap parameter sudah bermakna secara teoritis dan nyata secara statistik. 


\section{Pengujian Asumsi Klasik}

Untuk mendapatkan Best Linier Unbiased Estimator (BLUE), beberapa asumsi Klasik akan diuji. Untuk mengetahui keberadaan heterokedastisitas, penelitian ini menggunakan uji White. Dari Tabel 8 dapat dilihat bahwa probabilitas nilai uji, baik chi-square maupun $F$, melebihi $5 \%$ sehingga kita tidak bisa menolak $H_{0}$. Dengan demikian, model ini tidak mengandung heteroskedastisitas.

Tabel 8. Hasil Uji Heteroskedastisitas

\begin{tabular}{lccc}
\hline \multicolumn{1}{c}{ F-statistic } & 0.505047 & Prob. F $(9,15)$ & 0.8489 \\
\hline Obs $^{*}$ R-squared & 5.813925 & Prob. Chi-Square(9) & 0.7584 \\
\hline $\begin{array}{l}\text { Scaled } \\
\text { explained SS }\end{array}$ & 2.221833 & Prob. Chi-Square(9) & 0.9875
\end{tabular}

Untuk mendeteksi masalah autokorelasi digunakan Uji LM Test. Dari Tabel 8 dapat diketahui bahwa Nilai Chi square hitung sebesar 5,075751. Masalah autokorelasi dilihat berdasarkan nilai probabilitas Chi square yaitu sebesar 0.0790 pada kelambanan 2 berarti kita menerima hipotesis nul karena tingkat signifikansi a lebih besar dari 5\% yaitu 7,9\%. Maka secara statistik tidak signifikan sehingga model tidak mengandung masalah autokorelasi.

Tabel 9. Hasil Uji Autokorelasi

\begin{tabular}{llll}
\hline Breusch-Godfrey Serial Correlation LM Test: & \\
\hline F-statistic & 1.655891 & Prob. F(2,13) & 0.2288 \\
\hline Obs*R-squared & 5.075751 & Prob. Chi-Square(2) & 0.0790 \\
\hline
\end{tabular}

Berbagai uji signifikansi, yakni uji $t$ dan $F$, berasumsi bahwa residual dari regresi yang dilakukan berdistribusi normal. Dengan menggunakan uji Jarque Bera, dapat ditunjukkan bahwa error term terdistribusi normal karena nilai probabilitas sebesar 0,767166 yang lebih besar dari taraf nyata $(\alpha=5 \%)$ 


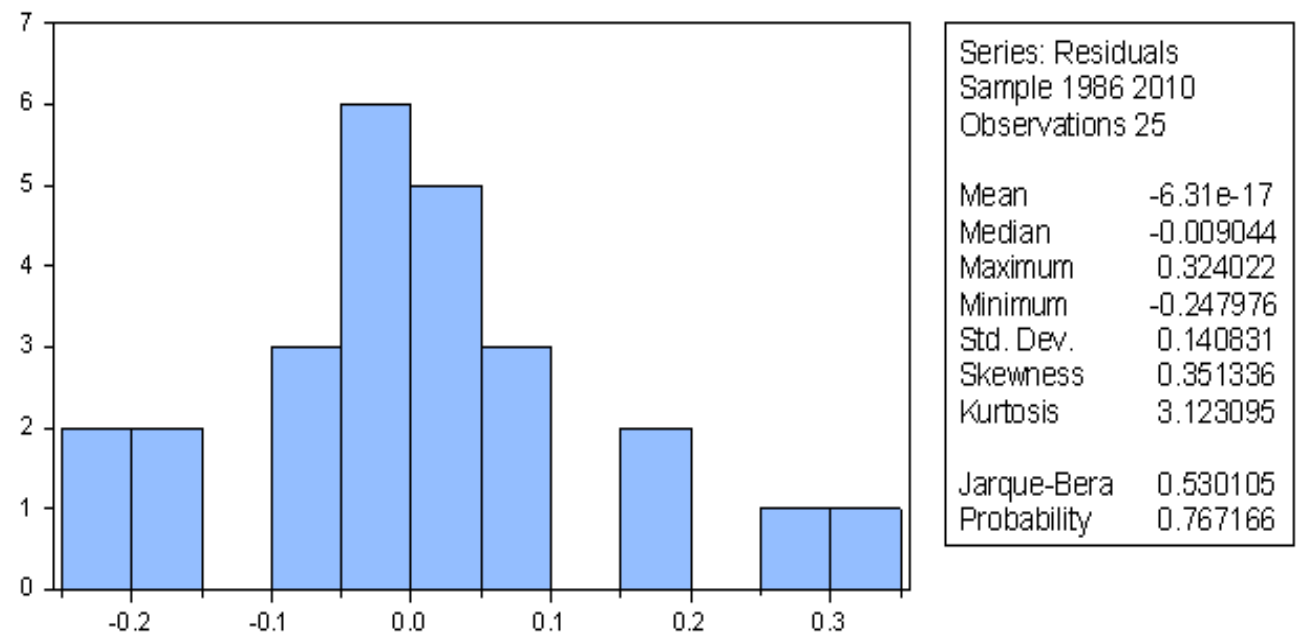

Gambar 1. Uji Normalitas dengan Statistik Jarque-Bera

\section{Pembahasan Hasil Penelitian}

Hasil analisis regresi dengan ECM menemukan bahwa secara serentak produksi nasional $\left(\log X_{1}\right)$, pendapatan perkapita $\left(\log X_{2}\right)$, ekspor susu $\left(\log X_{3}\right)$, jumlah balita $\left(\log X_{4}\right)$, jumlah penduduk non balita $\left(\log X_{5}\right)$, harga riil susu domestik (log $\left.X_{6}\right)$, harga riil susu impor $\left(\log X_{7}\right)$, kurs dalam bentuk IDR/USD $\left(\log X_{8}\right)$, dan dummy penghapusan kebijakan rasio impor berpengaruh secara signifikan terhadap variabel impor susu dengan besarnya pengaruh sebesar $78,79 \%$ dan sisanya $(21,21 \%)$ dijelaskan oleh variabel lain yang tidak dianalisis dalam model regresi ini.

Hasil pengujian secara parsial menemukan bahwa produksi dalam negeri tidak berpengaruh signifikan terhadap impor susu. Hal ini diduga terdapat variabelvariabel antara yang mempengaruhi impor susu dan tidak dapat dijelaskan dalam persamaan model struktural faktor-faktor yang mempengaruhi impor susu dalam jangka pendek yang dibangun dalam penelitian ini. Perkembangan selera (taste) masyarakat yang senantiasa berubah maupun perkembangan kesadaran (awareness) akan manfaat susu bagi kesehatan, jargonisasi "white revolution" yang dipopulerkan oleh negara-negara eksportir susu dunia, serta faktor-faktor eksternal lainnya yang mempengaruhi penawaran impor diduga mempengaruhi impor susu Indonesia. Implikasi dari argumentasi ini adalah peningkatan volume produksi susu domestik tidak akan secara langsung mempengaruhi impor susu pada jangka pendek.

Hasil pengujian menemukan bahwa pendapatan per kapita berpengaruh negatif terhadap impor susu. Selanjutnya, penelitian ini juga menemukan bahwa ekspor susu tidak berpengaruh negatif terhadap impor susu di Indonesia. Hal 
ini disebabkan karena isu kualitas bahan baku susu domestik yang kerapkali berada di bawah standar IPS (Indusri Pengolahan Susu), sehingga jumlah ekspor susu tidak tergantung banyak sedikitnya produksi susu nasional, tetapi susu yang berkualitas saja yang masuk dalam kriteria ekspor.

Variabel jumlah balita tidak berpengaruh terhadap impor susu di Indonesia. Hal ini kemungkinan disebabkan karena balita bukan sebagai konsumen terbesar yang mengkonsumsi susu tetapi cukup merata dari berbagai kalangan usia. Hal ini diperkuat oleh temuan bahwa variabel jumlah penduduk non balita berpengaruh positif terhadap impor susu.

Harga riil domesitik terbukti berpengaruh negatif terhadap impor susu. Hasil ini bertentangan dengan hipotesis penelitian yang menyatakan bahwa harga riil susu domestik berpengaruh positif terhadap impor susu. Hal ini dikarenakan negosiasi harga melalui sistem kontrak antara GKSI (Gabungan Koperasi Susu Indonesia) sebagai respresentasi dari peternak sapi perah dan IPS sebagai pihak yang merefleksikan kekuatan permintaan hanya mengakomodasi kepentingan dan kebutuhan IPS secara sepihak. Posisi tawar GKSI yang lemah disebabkan oleh tiga hal. Pertama, minimnya kapasitas produksi bahan baku susu domestik dalam menghadapi kekuatan permintaan yang jauh lebih besar. Kedua, saluran pemasaran susu segar yang dipasarkan kepada IPS untuk disutilisasi sebagai bahan baku susu domestik merupakan saluran utama pemasaran yang dilakukan. Ketergantungan akan saluran tersebut dan kurang berkembangnya alternatif saluran pemasaran lain menjadikan IPS sebagai oligopsonis dapat berkolusi menetapkan harga. Ketiga, isu kualitas bahan baku susu domestik yang kerapkali berada di bawah standar IPS dengan konsekuensi penalti mengakibatkan harga yang diterima pada farmgate level belum dapat merangsang pengembangan usaha peternakan sapi perah.

Harga riil susu impor terbukti berpengaruh positif dan signifikan terhadap impor susu. Hasil ini juga bertentangan dengan hipotesis yang menyatakan bahwa tingginya harga riil impor susu akan menurunkan impor susu. Kondisi ini berkaitan dengan asumsi klasik yang mengemukakan bahwa perilaku harga bersifat kaku (sticky price) pada perekonomian jangka pendek, sehingga harga riil impor diekspektasikan tidak akan berubah secara drastis di tahun berikutnya. Implikasinya adalah akan meningkatkan impor susu untuk mengantisipasi peningkatan harga yang lebih tinggi lagi dalam jangka panjang. Kekakuan harga ini dimungkinkan mengingat terkadang harga ditetapkan dalam kontrak jangka panjang antara perusahaan dan pelanggan. Bahkan, tanpa kesepakatan formal perusahaan dapat melaksanakan strategi untuk mempertahankan harga di level tertentu agar tidak merepotkan pelanggan tetap mereka dengan sering terjadinya perubahan harga (untuk diskusi lebih jauh tentang sticky price, silahkan baca Chari dkk. (2002)). 
Nilai tukar rupiah berpengaruh positif terhadap impor susu. Hal ini berarti semakin tinggi nilai tukar rupiah terhadap dollar maka impor susu akan semakin meningkat. Depresiasi Rupiah yang terjadi pada lag pertama mengakibatkan harga riil susu domestik menjadi lebih murah dibandingkan dengan harga riil impor yang telah dikonversi dengan nilai tukar. Hal ini mengakibatkan IPS meningkatkan preferensinya untuk menyerap susu domestik dan secara aktual akan menurunkan kegiatan impor susu. Pergerakan nilai tukar diekspektasikan akan relatif stabil atau hanya berfluktuasi dalam kisaran yang kecil pada jangka pendek. Bank Indonesia sebagai otoritas moneter mempunyai fungsi sebagai stabilisator yang meminimalisasi resiko pasar (market risk) yang diakibatkan oleh pergerakan nilai tukar agar tidak memperburuk kondisi makroekonomi Indonesia. Tingginya kredibilitas Bank Indonesia di mata pelaku pasar dalam hal stabilisasi nilai tukar mengakibatkan IPS sebagai salah satu pihak yang menggeluti kegiatan impor akan berperilaku rasional dengan mengurangi impor susu akibat depresiasi nilai tukar riil Rupiah pada lag pertama.

Kebijakan pemerintah terhadap penghapusan impor susu tidak berpengaruh positif terhadap impor susu nasional. Artinya ketika kebijakan penghapusan rasio impor diterapkan, tidak akan mengakibatkan kenaikan volume impor bahan baku susu. Kebijakan penghapusan rasio impor yang mencerminkan minimalisasi intervensi pemerintah dalam rangka mendorong efisiensi industri persusuan nasional telah memberikan pilihan yang lebih bebas dan luas untuk melakukan penyerapan impor bahan baku susu tanpa melalui prasyarat penyerapan bahan baku susu domestik. Semenjakkebijakan tersebutdiberlakukan industri persusuan nasional mengarah pada mekanisme pasar karena telah menghilangkan suatu bentuk distorsi perdagangan. Penerapan penghapusan kebijakan rasio impor yang dapat diartikan sebagai perluasan akses untuk melakukan impor bahan baku susu relatif kecil mempengaruhi peningkatan volume impor bahan baku susu pada jangka pendek. Hal ini diduga disebabkan oleh waktu penerapan penghapusan kebijakan rasio impor yang relatif bersamaan dengan krisis ekonomi yang terjadi di Indonesia di tahun 1998. Hal ini juga disebabkan karena krisis ekonomi yang terjadi di Indonesia, setidaknya mengakibatkan dua hal. Krisis telah memicu kenaikan harga secara umum (tingkat inflasi) dan depresiasi tajam nilai tukar riil Rupiah. Tingginya inflasi mengakibatkan penurunan daya beli masyarakat serta penurunan aktivitas importasi IPS. Dengan demikian kebijakan penghapusan susu sejak tahun 2009 dalam jangka pendek belum mempengaruhi peningkatan impor susu, karena kondisi ekonomi yang masih krisis menyebabkan daya beli konsumen masih rendah. 


\section{KESIMPULAN}

Berdasarkan hasil regresi ECM dapat ditarik kesimpulan sebagai berikut. Pertama, faktor-faktor yang mempengaruhi impor susu tahun 1985-2010 jangka panjang di Indonesia adalah: variabel pendapatan per kapita, harga riil susu domestik, dan harga susu impor. Hasil penelitian menemukan bahwa pendapatan per kapita dan harga riil susu domestik berpengaruh negatif terhadap impor susu, sedangkan harga riil susu impor berpengaruh positif terhadap impor susu dalam jangka panjang. Kedua, faktor-faktor yang mempengaruhi impor susu tahun 1985-2010 jangka pendek di Indonesia adalah: jumlah penduduk non balita, harga riil susu domestik, harga riil susu impor, nilai tukar rupiah terhadap dollar. Hasil penelitian menemukan jumlah penduduk non balita, harga susu impor dan nilai tukar rupiah berpengaruh positif terhadap impor susu, sedangkan harga riil susu domestik berpengaruh negatif terhadap impor susu dalam jangka pendek. Ketiga, produksi nasional, ekspor susu, jumlah balita, dan kebijakan pemerintah penghapusan impor susu tidak berpengaruh secara signifikan terhadap impor susu dalam jangka pendek maupun jangka panjang.

Berdasarkan hasil kesimpulan maka dapat diusulkan beberapa saran sebagai berikut. Pertama, bagi pelaku bisnis, upaya peningkatan produksi susu domestik dalam jangka pendek krusial untuk dilaksanakan melalui penambahan populasi sapi betina, perbaikan pemberian pakan dan tata laksana, dan intensifikasi pelaksanaan Inseminasi Buatan. Kedua, efek penghapusan kebijakan rasio impor yang ditetapkan oleh pemerintah per tahun 1998 berupa peningkatan volume impor susu dapat diatasi dengan exit strategy peningkatan produksi susu domestik. Ketiga, pemerintah perlu memberikan dukungan nyata dalam rangka mengembangkan usaha peternakan sapi perah pada khususnya, seperti kemudahan akses usaha peternakan sapi perah terhadap kredit serta pendanaan bagi program penelitian dan pengembangan susu domestik. Tujuan utama peningkatan kapasitas produksi dan kualitas susu domestik merupakan langkah prioritas yang perlu dilakukan dengan segera dalam jangka pendek. Juga perlu dilakukan perbaikan sarana transportasi sangat penting, karena susu segar yang dihasilkan oleh para peternak tidak dapat di angkut ke luar daerah apabila kontur aspal kurang baik. Guncangan yang muncul akibat kontur jalan yang buruk akan menyebabkan rusaknya susu segar karena terjadi kristalisasi sehingga susu segar yang sudah dihasilkan tidak dapat di proses lebih lanjut. Hal ini juga yang menjadi alasan mengapa Indonesia mengimpor susu dalam bentuk bubuk. Diharapkan pemerintah dapat fokus dalam pembenahan sarana transportasi demi keberlangsungan industry persusuan di Indonesia. 


\section{DAFTAR PUSTAKA}

Ahmad, I. dan Hermiyetti (2008), "Analisis Produksi dan Konsumsi Susu di Indonesia," Semiloka Nasional Prospek Industri Sapi Perah Menuju Perdagangan Bebas, 2020.

Amaliah, S. dan I. Fahmi (2008), "Faktor-Faktor yang Mempengaruhi Daya Saing dan Impor Susu Indonesia Periode 1976-2005," Jurnal Manajemen dan Agribisnis, 4(2), 91-102 Amaliah dan Fahmi

Chari, V.V., P.J. Kehoe dan E.R. McGrattan (2002), "Can Sticky Price Models Generate Volatile and Persisten Real Exchange Rates?" Review of Economic Studies, 69, 533-563.

Direktorat Jenderal Peternakan (2010), Statistik Peternakan 2010, Jakarta: Direktorat Jenderal Peternakan.

Engle, R.F. dan C.W.J. Granger (1987), "Co-integration and Error Correction: Representation, Estimation, and Testing," Econometrica, 55, 251-276.

Halwani, H. (2002), Ekonomi Internasional dan Globalisasi Ekonomi, Ghalia Indonesia, Bogor.

Isbandriyati, M. (2009), "The Impact of Final Demand arld Prices on Indonesia's Total - Import: Cointegration and Error Correction Model Analysis," Jurnal Ekonomi dan Pembangunan Indonesia, 9(2), 109-125

Kustiari, R., A. Priyanti, dan Erwidodo (2008), "Kebijakan Impor Susu: Melindungi Peternak Dan Konsumen," Semiloka Nasional Prospek Industri Sapi Perah Menuju Perdagangan Bebas - 2020.

Sinaulan, J.H. (1994), "Faktor-Faktor yang Mempengaruhi Tingkat Permintaan dan Penawaran Susu Sapi Perah di Jawa Barat," Buletin Imiah Tarumanegara, Tahun 9 No. 31.

Siregar, H. (2004), Analisis Permintaan Ekspor CPO Indonesia: Suatu Pendekatan Error Correction Model (ECM), Skripsi Sarjana, Fakultas Pertanian, Institut Pertanian Bogor.

Siregar, S.B. (2003), "Peluang dan Tantangan Peningkatan Produksi Susu Nasional," Wartazoa, 13, 48-53.

Sjoholm, S. dan L. Lindh (1997), VHDL for Designers, Prentice Hall Europe, Maylands Avenue, British.

Sutomo, B. dan D.Y. Anggraini (2010), Makanan Sehat Pendamping ASI, Demedia, Jakarta. 